\title{
Temperate Phages Influencing Lipase Production by Staphylococcus aureus
}

\author{
By KIRSTEN ROSENDAL AND P. BÜLOW \\ Diagnostic Department, Statens Seruminstitut, Copenhagen, Denmark
}

(Received 26 July 1965)

\begin{abstract}
SUMMARY
Phages capable of changing the production of the 'Tween'-splitting enzyme by lysogenic conversion of Staphylococcus aureus strains were isolated from lysogenic strains within the phage type 52/52A/80/81 complex.

Phages isolated from TW- strains were able to block the production of the 'Tween'-splitting enzyme when they lysogenized TW+ strains. When the $\mathbf{T W}^{+}$receptor strains were originally lysogenic, double lysogenization occurred. This change in the 'Tween' reaction was shown to be an example of lysogenic conversion. Phages isolated from $\mathbf{T W}^{+}$strains were found able, in some instances, to change $\mathrm{TW}^{-}$strains to $\mathrm{TW}^{+}$strains on lysogenization. This change in reaction was found to be due to loss of the converting phage carried by the recipient strains by prophage substitution. Where prophage substitution did not occur and the strains became doubly lysogenic, the strains remained TW-.

In these experiments a change of the typing pattern was found after lysogenization. The phage type of the lysogenized strain became similar to that of the donor strain. Non-typable strains were found, doubly lysogenic for phages which between them blocked all the reactions to the typing phages employed. The significance of these findings is discussed, especially the use of lysogenized strains in experiments designed to investigate the role of 'Tween' negavity as a virulence factor.
\end{abstract}

\section{INTRODUCTION}

Previous investigations of staphylococcal bacteraemia cases (Jessen et al. 1963) indicated that Staphylococcus aureus strains which did not produce a 'Tween'splitting enzyme ( $\mathrm{TW}^{-}$) might be more virulent than those which did produce the enzyme $\left(\mathrm{TW}^{+}\right)$. Further investigations into factors influencing this enzyme production by Staphylococcus aureus strains showed that it was possible by lysogenization to make TW' ${ }^{+}$strains TW- (Rosendal, Bülow \& Jessen, 1964).

It was concluded, from these experiments that a lysogenic conversion took place, since all colonies made TW- were lysogenic, and loss of the prophage caused a reversion to 'Tween' positivity. Furthermore, the converting property of the phages was not influenced bythe 'Tween'-splitting property of the last strain on which the phages were propagated.

The phages with converting properties were all isolated from $\mathbf{T W}^{-}$strains lysed only by typing phage 80 , whereas the sensitivity to phage 81 was blocked. On lysogenization the $\mathrm{TW}^{+}$receptor strains, which all belonged to phage type $80 / 81$, became TW- $^{-}$and resistant to phage 81 . 
The present survey includes further investigations into temperate phages isolated from both $\mathrm{TW}^{-}$and $\mathrm{TW}^{+}$strains belonging to the 52/52A/80/81 phage type complex (types 80,81, 80/81, 52/52A/80 and 52/52A/80/81) and all capable of changing the 'Tween'-splitting properties of sensitive strains by lysogenic conversion or by prophage substitution of converting phages present in the $\mathbf{T W}$ - strains.

\section{METHODS}

'Tween'-splitting enzyme was shown on 'Tween' 80/calcium agar plates (Sierra, 1957).

Staphylococcal strains. A list of the lysogenic strains from which the phages were isolated is given in Table 1.

Table 1. Phage types of the donor strains and their non-lysogenic mutants

\begin{tabular}{|c|c|c|c|c|c|}
\hline \multirow[b]{2}{*}{ Strain } & \multirow[b]{2}{*}{ TW } & \multicolumn{2}{|c|}{ Phage types } & \multirow{2}{*}{$\begin{array}{l}\text { Phage } \\
\text { iso- } \\
\text { lated o }\end{array}$} & \multirow{2}{*}{$\begin{array}{l}\text { Serol. } \\
\text { group } \\
\text { of phage }\end{array}$} \\
\hline & & RTD & $1000 \times$ RTD & & \\
\hline 24724 & - & 80 & $52 / 52 \mathrm{~A} / 80 / 47 \mathrm{C} / 52 \mathrm{~B}$ & + & $\mathbf{A}$ \\
\hline 24724 & + & $80 / 81 / 42 B / 47 C$ & $52 / 52 \mathrm{~A} / 80 / 81 / 42 \mathrm{~B} / 47 \mathrm{C} / 52 \mathrm{~B}$ & - & \\
\hline 311 & - & 80 & $52 / 80 / 47 \mathrm{C}$ & + & $\mathbf{F}$ \\
\hline 311 & + & $80 / 81$ & $52 / 52 \mathrm{~A} / 80 / 81 / 42 \mathrm{~B} / 47 \mathrm{C}$ & - & \\
\hline 1543 & - & $52 / 52 \mathrm{~A} / 80 / 81 / 42 \mathrm{~B} / 47 \mathrm{C}$ & $52 / 52 \mathrm{~A} / 80 / 81 / 42 \mathrm{~B} / 47 \mathrm{C} / 52 \mathrm{~B}$ & + & $\mathbf{A}$ \\
\hline 1543 & + & $80 / 81 / 42 B / 47 \mathrm{C}$ & $52 / 52 \mathrm{~A} / 80 / 81 / 42 \mathrm{~B} / 47 \mathrm{C} / 52 \mathrm{~B}$ & - & \\
\hline 11352 & - & $81 / 47 \mathrm{C}$ & $81 / 42 B / 47 C$ & + & $\mathbf{B}$ \\
\hline 11352 & + & $52 / 52 \mathrm{~A} / 80 / 81 / 47 \mathrm{C} / 52 \mathrm{~B}$ & $52 / 52 A / 80 / 81 / 54 / 42 B / 47 C / 52 B$ & - & \\
\hline 1400 & - & 81/42B & $81 / 42 B$ & + & $\mathbf{B}$ \\
\hline 1400 & + & $52 / 52 \mathrm{~A} / 80 / 81 / 42 \mathrm{~B} / 52 \mathrm{~B}$ & $29 / 52 / 52 \mathrm{~A} / 80 / 81 / 42 \mathrm{~B} / 52 \mathrm{~B}$ & - & \\
\hline 327 & + & $52 / 52 \mathrm{~A} / 80 / 52 \mathrm{~B}$ & $52 / 52 \mathrm{~A} / 80 / 52 \mathrm{~B}$ & + & $\mathbf{A}$ \\
\hline 7578 & + & $52 / 52 \mathrm{~A} / 80 / 81 / 42 \mathrm{~B} / 47 \mathrm{C} / 52 \mathrm{~B}$ & $52 / 52 \mathrm{~A} / 80 / 81 / 42 \mathrm{~B} / 47 \mathrm{C} / 52 \mathrm{~B}$ & + & $\mathbf{A}$ \\
\hline 1483 & + & $81(42 \mathrm{~B} / 47 \mathrm{C} \mathrm{vw} *)$ & $81 / 42 \mathrm{~B} / 47 \mathrm{C} / 52 \mathrm{~B}$ & + & $\mathbf{B}$ \\
\hline
\end{tabular}

From all the $\mathbf{T W}^{-}$strains $\mathbf{T W}^{+}$variants were isolated with a frequency of about 10-4. (Four-hr cultures grown in trypsin broth with $2 \times 10^{-2} \mathrm{M}$-sodium citrate added were spread on 10 'Tween'/calcium agar plates to give about $5 \times 10^{3}$ colonyforming units per plate. $\mathrm{TW}^{+}$colonies were easily seen among the great majority of TW- ones).

Several other $\mathrm{TW}^{-}$and $\mathrm{TW}^{+}$strains belonging to phage types $80,81,80 / 81$, 52/52A/80 and 52/52A/80/81 were used to investigate the lysogenic effect of the various phages. Some of them were selected as indicator strains for the phages.

Phages were isolated from the strains listed in Table 1, using the chloroform method of Kjems (1955). They were propagated to a titre of about $10^{\circ} \mathrm{ml}$. as suggested by Blair \& Williams (1961). Their antigenic characters were determined by Rountree's method (1949). The phages are designated by the number of their staphylococcal strain of origin followed by a prime sign. Several other phages with lysogenic properties identical to those referred to have been investigated but details are given only of one representative of each group.

Lysogenization was carried out as described by Rountree (1959). The lysogenized cultures were tested for resistance to the lysogenizing phage and for phage produc- 
tion by the chloroform method (Kjems, 1955). Phage production was confirmed by applying the replica test (Lederberg \& Lederberg, 1952) to living cultures passaged three times through medium containing anti-phage serum. In investigating double lysogeny two different indicator strains, each lysed by only one of the phages in question, were used.

The lysogenized cultures are described in the usual way, e.g. 24724 $\left(311^{\prime}\right)$ is strain 24724 lysogenized with phage 311' isolated from strain 311.

Phage-typing was done by the method of Blair \& Williams (1961). The phages used were those described by Rosendal, Stenderup, Helms \& Eriksen (1963).

\section{RESULTS}

Relation between lysogeny and the 'Tween' reaction. From Table 1 it is seen that none of the $\mathrm{TW}^{+}$variants isolated from the $\mathrm{TW}^{-}$cultures was shown to produce phage. They were easily lysogenized by phages from the parent culture which made them TW- and blocked all the reactions to the typing phages by which they differed from the corresponding $\mathrm{TW}^{-}$strain, their phage pattern in most cases being broader.

None of the strains lysed by typing phage 80 was completely resistant to the phages 52 and $52 \mathrm{~A}$ which were able to lyse them at $1000 \times \mathrm{RTD}$, whereas in the strains not lysed by phage 80 , but by phage 81 , the block to phages 52 and $52 \mathrm{~A}$ was complete.

However, some $\mathrm{TW}^{+}$strains were found to be phage producing $(\mathbf{3 2 7}, 1433$ and 7578), and their phages were also investigated.

All the phages referred to in Table 1 must be considered temperate, since they were able to lysogenize.

Effect of lysogenization on phage-typing pattern. Tables 2 and 3 give information about the changes in sensitivity to typing phages which took place after lysogenization with the various phages. The changes caused by phages isolated from TWstrains are recorded in Table 2 , those caused by phages from $\mathrm{TW}^{+}$strains in Table 3. The results were obtained by lysogenizing a variety of strains within the type 52/52 A/80/81 complex. It will be seen that some phages were able to block certain reactions, whereas others remain unchanged, depending upon the phage used. In some cases a gain in sensitivity was achieved. When, for instance, a type 81 was lysogenized by a phage from type 80 , the lysogenized culture could be typed as type 80. Phage $1543^{\prime}$ did not block any of the reactions examined.

When TW- cultures were lysogenized with the phages $327^{\prime}, \mathbf{1 4 3 3}^{\prime}$ and 7578', both $\mathbf{T W}^{-}$and $\mathrm{TW}^{+}$representatives, with phage pattern indicating lysogenization, were isolated.

Prophage substitution and double lysogenization. In previous experiments (Rosendal et al. 1964) the converting property of the phages was shown by using receptor strains not known to be lysogenic, therefore it could not be shown whether a prophage substitution was responsible for the change of the 'Tween'splitting property or not. So converting experiments were performed using only strains lysogenized with a demonstrable prophage and phages which were able to lyse or lysogenize these strains (Table 4).

From the results it is evident that a prophage substitution took place only when $\mathrm{TW}^{-}$strains became $\mathrm{TW}^{+}$upon lysogenization. When these cultures still retained their 
Table 2. Effect of lysogenization with phages blocking the production of the 'Treen'-splitting enzyme on reaction to typing phages

\begin{tabular}{|c|c|c|c|c|c|c|c|c|}
\hline \multirow[b]{2}{*}{ Phage } & \multirow{2}{*}{$\begin{array}{c}\text { Phage type of } \\
\text { donor strain }\left(\mathrm{TW}^{-}\right)\end{array}$} & \multicolumn{7}{|c|}{ Typing phages } \\
\hline & & 52 & $\mathbf{5 2 A}$ & 80 & 81 & $42 B$ & $47 \mathrm{C}$ & 52B \\
\hline $24724^{\prime}$ & 80 & $\times$ & $x$ & $o$ & $x$ & $x$ & $x$ & $x$ \\
\hline $311^{\prime}$ & $\mathbf{8 0}$ & $x$ & $x$ & - & $x$ & $x$ & 0 & $x$ \\
\hline $1543^{\prime}$ & $52 / 52 \mathrm{~A} / 80 / 81 / 42 \mathrm{~B} / 47 \mathrm{C}$ & $o$ & $o$ & $o$ & 0 & 0 & $o$ & 0 \\
\hline $11352^{\prime}$ & $81 / 47 \mathrm{C}$ & $x$ & $x$ & $\times$ & $o$ & - & - & $x$ \\
\hline $1400^{\prime}$ & $81 / 42 B$ & $x$ & $x$ & $x$ & $o$ & $\boldsymbol{o}$ & $x$ & $x$ \\
\hline
\end{tabular}

$x$ indicates blocking of sensitivity.

- indicates no blocking of sensitivity.

$o$ indicates gain in sensitivity.

Table 3. Effect of lysogenization with phages capable of making $T W^{-}$cultures enzyme producing. Alteration of reaction to typing phages

\begin{tabular}{|c|c|c|c|c|c|c|c|c|}
\hline \multirow[b]{2}{*}{ Phage } & \multirow{2}{*}{$\begin{array}{c}\text { Phage type of } \\
\text { donor strain }\left(\mathrm{TW}^{+}\right)\end{array}$} & \multicolumn{7}{|c|}{ Typing phages } \\
\hline & & 52 & $\mathbf{5 2 A}$ & 80 & 81 & 42B & $47 \mathrm{C}$ & 52B \\
\hline 327' & $52 / 52 A / 80 / 52 B$ & 0 & $o$ & $o$ & $x$ & $x$ & $x$ & 0 \\
\hline $7578^{\prime}$ & $52 / 52 \mathrm{~A} / 80 / 81 / 42 \mathrm{~B} / 47 \mathrm{C} / 52 \mathrm{~B}$ & 0 & $\boldsymbol{o}$ & $o$ & 0 & - & - & 0 \\
\hline 1433' & $81(42 B / 47 C$ vw*) & $x$ & $x$ & $x$ & 0 & 0 & o & $x$ \\
\hline
\end{tabular}

'Tween' negativity even though lysogenized with the phages 327 ' or 1433 ', they had become double lysogenic and were still carrying their original prophage, as evidenced by resistance to and production of both phages in question and change of phage type.

Both the $\mathrm{TW}^{+}$lysogenic cultures were still lysogenic for the original prophage when they were lysogenized with a phage which made them TW-.

An experiment was done to find out whether these phages, derived from $\mathbf{T W}^{+}$ cultures, in fact substituted for the converting prophage or whether the TW $^{+}$ lysogenized individuals originated from lysogenization of $\mathrm{TW}^{+}$mutants present in the original culture. In this experiment phage 327' was used as a representative of the phages which can convert $\mathrm{TW}^{-}$strains. A culture of $311\left(\mathrm{TW}^{-}\right)$in a suitable concentration to give single colonies was grown on 'Tween' agar for $2 \mathrm{hr}$, so that less than 100 cocci per colony-forming unit might be expected. This plate was used as a master plate for transfer by replica technique to an extract agar plate flooded with $327^{\prime}\left(10^{9}\right.$ phage particles $/ \mathrm{ml}$.). After overnight incubation at $30^{\circ}$ this plate in turn was transferred to a second 'Tween' agar plate. It was found that 48 out of 66 originally $\mathrm{TW}^{-}$colonies had been converted to $\mathrm{TW}^{+}$. One of the converted colonies was cut out of the master plate and transferred to broth with $2 \times 10^{-2} \mathrm{M}$-sodium citrate added. After growth at $37^{\circ}$ for $2 \frac{1}{2} \mathrm{hr}$ one $\mathrm{ml}$ of a $10^{-3}$ dilution was spread onto 10 'Tween' agar plates, giving a growth of about 5000 colonies per plate. 
Table 4. Presence of prophage(s) in various cultures before and after lysogenization with phages capable of changing the Tween splitting property of the culture

\begin{tabular}{|c|c|c|c|c|c|c|c|}
\hline \multirow[b]{2}{*}{ Strain } & \multirow[b]{2}{*}{ Phage type } & \multirow[b]{2}{*}{ TW } & \multicolumn{5}{|c|}{ Lysed by phages } \\
\hline & & & 311 & 1543 & 11352 & 327 & 1433 \\
\hline 311 & 80 & - & - & . & . & + & + \\
\hline $311\left(327^{\prime}\right)$ & $52 / 52 A / 80 / 52 B$ & + & + & . & . & - & . \\
\hline $311\left(327^{\prime}\right)$ & $52 / 52 A / 80 / 52 B$ & - & - & . & . & - & . \\
\hline $311\left(1433^{\prime}\right)$ & $81 / 47 \mathrm{C}$ & + & + & . & . & . & - \\
\hline $311\left(1433^{\prime}\right)$ & $47 \mathrm{C}$ & - & - & . & . & . & - \\
\hline 1543 & $52 / 52 \mathrm{~A} / 80 / 81 / 42 \mathrm{~B} / 47 \mathrm{C}$ & - & - & - & . & + & + \\
\hline $1543\left(327^{\prime}\right)$ & $52 / 52 A / 80 / 52 B$ & + & . & + & . & - & . \\
\hline $1543\left(327^{\prime}\right)$ & $52 / 52 A / 80 / 52 B$ & - & . & - & . & - & . \\
\hline $1543\left(1433^{\prime}\right)$ & $81 / 42 B / 47 C$ & + & . & + & - & . & - \\
\hline $1543\left(1433^{\prime}\right)$ & $81 / 42 B / 47 C$ & - & . & - & - & . & - \\
\hline 11352 & $81 / 47 \mathrm{C}$ & - & . & . & - & + & - \\
\hline $11352\left(327^{\prime}\right)$ & $52 / 52 A / 80 / 52 B$ & + & . & . & + & - & . \\
\hline $11352\left(327^{\prime}\right)$ & NTt & - & . & . & - & - & - \\
\hline 327 & $52 / 52 A / 80 / 52 B$ & + & + & . & + & - & . \\
\hline $327\left(311^{\prime}\right)$ & 80 & - & - & . & . & - & . \\
\hline $327\left(11352^{\prime}\right)$ & NT & - & . & . & - & - & . \\
\hline 1483 & $81(42 B / 47 C$ vw*) & + & + & . & - & + & - \\
\hline $1433\left(311^{\prime}\right)$ & $47 C$ & - & - & - & . & . & - \\
\hline
\end{tabular}

\begin{tabular}{|c|c|c|}
\hline $\begin{array}{l}\text { Phage(s) } \\
\text { produced }\end{array}$ & $\begin{array}{c}\text { Pro- } \\
\text { phage } \\
\text { substitu- } \\
\text { tion }\end{array}$ & $\begin{array}{c}\text { Doubl } \\
\text { lyso- } \\
\text { geniza } \\
\text { tion }\end{array}$ \\
\hline 311 & . & \\
\hline 327 & + & 一 \\
\hline 311,327 & - & + \\
\hline 1433 & + & - \\
\hline 311,1483 & - & + \\
\hline 1543 & . & \\
\hline 327 & + & - \\
\hline 1543,327 & - & + \\
\hline 1433 & + & - \\
\hline 1543,1433 & - & + \\
\hline 11352 & . & . \\
\hline 327 & + & - \\
\hline 11352, 327 & - & + \\
\hline 327 & . & - \\
\hline 327,311 & - & + \\
\hline 327,11352 & - & + \\
\hline 1433 & . & \\
\hline 1433, 311 & - & + \\
\hline
\end{tabular}


Only $14 \mathrm{TW}^{+}$colonies were found amongst the 50,000 colonies, indicating that the $\mathrm{TW}^{+}$mutants in the original culture could not account for all the conversions found.

Table 5. Phage types after lysogenization

\begin{tabular}{|c|c|c|c|c|}
\hline Strain & Before lysogenization & TW & Prophage substitution & $\begin{array}{c}\text { Double } \\
\text { lysogeniza- } \\
\text { tion }\end{array}$ \\
\hline $311\left(1543^{\prime}\right)$ & 80 & - & $52 / 52 \mathrm{~A} / 80 / 81 / 42 \mathrm{~B} / 47 \mathrm{C}$ & $80 / 47 \mathrm{C}$ \\
\hline $1543\left(811^{\prime}\right)^{\prime}$ & $52 / 52 \mathrm{~A} / 80 / 81 / 4,2 \mathrm{~B} / 47 \mathrm{C}$ & - & $80 / 47 C$ & . \\
\hline $1543\left(24724^{\prime}\right)$ & $52 / 52 \mathrm{~A} / 80 / 81 / 42 \mathrm{~B} / 47 \mathrm{C}$ & - & 80 & $52 / 52 A / 80$ \\
\hline $24724\left(811^{\prime}\right)$ & 80 & - & $80 / 47 \mathrm{C}$ & 80 \\
\hline $24724\left(1543^{\prime}\right)$ & 80 & - & $52 / 52 A / 80 / 81$ & • \\
\hline $1488\left(327^{\prime}\right)$ & $81\left(42 B / 47 C v^{*}\right)$ & + & . & $\mathbf{N T} \dagger$ \\
\hline
\end{tabular}

No change of the 'Tween' reaction. Donor strain and receptor strain have the same 'Tween'splitting capacity.

$* \mathrm{vw}=$ very weak reaction. $\quad \dagger \mathrm{NT}=$ non-typable.

TW- strains carrying converting phages could themselves be lysogenized with converting phages from other $\mathrm{TW}^{-}$lysogenic strains (Table 5). Both prophage substitution and double lysogenization occurred. No effect was produced on the 'Tween'-splitting reaction as might be expected since both donor and recipient strains were $\mathrm{TW}^{-}$, but there was an effect on the phage-typing pattern which differed according to the lysogenization, depending on whether prophage substitution or double lysogenization took place. The changes in typing pattern corresponded to the changes expected on the basis of the results presented in Tables 2 and 3 . No prophage substitution was observed in strain $1433\left(327^{\prime}\right)$, which agreed with the previous finding that prophage substitution did not occur in lysogenic TW+ strains and suggests that the phages carried by $\mathrm{TW}^{+}$strains were more stably integrated than was the case with the $\mathrm{TW}^{-}$converting phages.

\section{DISCUSSION}

The assumption that there might exist a correlation between 'Tween' negativity and virulence originated from investigations of survival or death of about 500 patients with staphylococcal bacteraemia (Jessen et al. 1963). So far, however, it has not seemed possible to obtain experimental proof of this hypothesis as the selection of strains would have been too difficult. There would always have been some doubt whether the strains chosen were in fact comparable, they might differ in some unknown properties. But pairs of $\mathrm{TW}^{+}$staphylococcal strains before and after conversion to 'Tween' negativity do seem to be comparable and may offer information about differences in virulence and in biochemical properties. Now, a further question arises, is the lack of diffusible 'Tween'-splitting enzyme itself a virulence factor, or do some accompanying properties account for the enhancement of virulence?

If experiments showed that conversion to 'Tween' negativity was correlated with an increase of virulence, it would be another example of virulence in bacteria depending upon lysogenic conversion, the first and classical example of which is 
Corynebacterium diphtheriae (Freeman, 1951). In the present experiments it did seem that Tween negativity depended on the presence of a prophage, whereas Tween positivity did not. The $\mathrm{TW}^{-}$strains so far investigated have always been lysogenic, but only some $\mathbf{T W}^{+}$strains, and lysogeny has not been shown in the $\mathbf{T W}^{+}$variants of the TW- strains, although a large number of indicator strains were used. Furthermore, the phages isolated from $\mathrm{TW}^{+}$strains were only capable of 'converting' by virtue of prophage substitution and cannot be regarded as true converting phages like those carried by $\mathrm{TW}^{-}$strains.

In some instances the conversion of staphylococci provides a handy tool for isolating variants within a bacterial population. In $\mathrm{TW}^{-}$cultures the mutants having lost the prophage and therefore having become $\mathrm{TW}^{+}$were easily detected on the Tween medium, and in lysogenization experiments the lysogenized individuals were easily scored on Tween agar when a change of enzyme production had taken place. However, it must be born in mind that in TW- cultures lysogenized by phages 327' and 1433' the lysogenized individuals did not differ from the nonlysogenized ones unless a prophage substitution had occurred.

The similarity of the phage types of these $\mathrm{TW}^{+}$variants (Table 1 ) supports the theory of Rountree (1959) that the parent phage type of the 52/52 A/80/81 complex may be type 52/52 A/80/81/42B/47C/52B, and that all other phage types within the complex may originate from it by lysogenization with various phages.

The changes of phage type upon lysogenization agreed with those found by other authors (Rountree, 1959; Asheshov \& Rippon, 1959; Rountree \& Asheshov, 1961) and was understandable in view of what was shown about the outcome of lysogenization (prophage substitution or double lysogeny). Non-typable subcultures were also found in cultures which were doubly lysogenic for phages which between them blocked the reactions to all the typing phages in question. Comtois (1960) also found non-typable subcultures upon lysogenization, and supposed that the immunity to typing phages in these instances 'occurred in blocks'.

\section{REFERENCES}

Asheshov, E. H. \& Rippon, J. E. (1959). Changes in typing pattern of phage-type 80 staphylococci. J. gen. Microbiol. 20, 634.

Blair, J. E. \& Williams, R. E. O. (1961). Phage typing of Staphylococci. Bull. World Hlth Org. 24, 771.

Comrors, R. D. (1960). Changes in the phage-typing patterns of Staphylococci following lysogenization with a related group of Staphylococcus bacteriophages. Can. J. Microbiol. 6, 491.

Freeman, V. J. (1951). Studies on the virulence of bacteriophage-infected strains of Corynebacterium diphteriae. J. Bact. 61, 675.

Jessen, O., Rosendal, K., Faber, V., Hove, K. \& Eriksen, K. R. (1963). Some properties of Staphylococcus aureus, possibly related to pathogenicity. III. Bacteriological investigations of Staphylococcus aureus strains from 462 cases of bacteraemia. Acta path. microbiol. scand. 58, 85.

KJEMS, E. (1955). Studies on streptococcal bacteriophages. I. Technique of isolating phage-producing strains. Acta path. microbiol. scand. 36, 433.

LeDERBERG, J. \& LEDERBERG, E. M. (1952). Replica plating and indirect selection of bacterial mutants. J. Bact. 63, 379.

Rosendal, K., Bülow, P. \& JesSen, O. (1964). Lysogenic conversion in Staphylococcus aureus to a change in the production of extracellular 'Tween'-splitting enzyme. Nature, Lond. 204, 1222. 
Rosendal, K., Stenderup, A., Helms, P. \& Eriksen, K. R. (1963). Staphylococcus aureus strains isolated in Danish hospitals from April 1st to December 31st 1960. Acta path. microbiol. scand. 58, 72.

Rountree, P. M. (1949). The serological differentiation of staphylococcal bacteriophages. J. gen. Microbiol. 3, 164.

Rountree, P. M. (1959). Changes in the phage-typing patterns of staphylococci following lysogenization. J. gen. Microbiol. 20, 620.

Rountree, P. M. \& Asheshov, E. H. (1961). Further observations on changes in the phage-pattern of phage type 80/81 staphylococci. J. gen. Microbiol. 26, 111.

Sinrra, G. (1957). Simple method for the detection of lipolytic activity of micro-organisms and some observations on the influence of the contact between cells and fatty substrates. Antonie van Leeurvenhoek, 23, 15. 